\title{
Genetic diversity in a Brazilian bovine herd based on four microsatellite loci
}

\author{
Sabrina E. Matos Almeida ${ }^{1}$, Márcia S.N. Machado ${ }^{1,2}$, Clara Sabina Steigleder ${ }^{1}$, \\ Cleonice L. Gama ${ }^{1}$, Mara Helena Hutz, Luiz Ernani Henkes ${ }^{1}$, José Carlos F. Moraes ${ }^{3}$ and Tania de Azevedo Weimer ${ }^{1}$
}

\begin{abstract}
Microsatellites or short tandem repeats (STRs), DNA markers relatively abundant in the genome, have a high degree of polymorphism and therefore great potential for characterizing populations. The present study estimates genetic variability in a set of four microsatellites (BMS3013, BMS3004, HEL10 and TGLA122) in a Brazilian hybrid bovine breed (5/8 Aberdeen Angus x 3/8 Nelore). The objectives were to determine the effect of crossbreeding and selection in these animals' genetic diversity as well as to discover the herd's genetic relationship with that of other breeds. Low diversity was verified in BMS3013 and high diversity was detected in BMS3004, HEL10 and TGLA122. Two alleles in TGLA122 are described here for the first time (TGLA122*155 and TGLA122*163). These genes are possibly characteristics of Zebu animals since they have not been found in other taurine samples so far investigated. Low interpopulational diversity was observed among taurine cattle populations, and clusters obtained on TGLA122 phylogenetic trees agreed with the bovine herd's geographic origin. Therefore, despite TGLA122's high polymorphism and high levels of intrapopulational diversity, the system engenders consistent bovine phylogenies. We detected an intriguingly high similarity between Brangus Ibagé and Red Angus since the former is a hybrid having 3/8 of Nelore genes. Either these animals' environment or genetic selective practices applied to the breed probably favor the Angus genotype.
\end{abstract}

\section{INTRODUCTION}

In livestock species directed selection of economically desirable traits can lead to genetic erosion of individual cattle breeds. Therefore, genetic diversity maintenance provides a crucial base for new characteristic selection. An adequate method for verifying a herd's genetic diversity insures more accurate selection and higher quality products (Bradley et al., 1998). DNA-based technologies enable detection of different polymorphic types. Among these, microsatellites or short tandem repeats (STRs) have been identified in all eukaryotic species so far investigated (Tautz, 1993; Ron et al., 1996). Due to their relative abundance in the genomes and high polymorphism they are important tools in population characterization (MacHugh et al., 1997; Simonsen et al., 1998).

Brangus is a $3 / 8$ Brahman (Bos indicus) and 5/8 Angus (Bos taurus) breed fitted to a wide climate and feed range (Keeling, 1997). In Southern Brazil, the Brazilian Agricultural Research Corporation (Empresa Brasileira de Pesquisa Agropecuária, EMBRAPA/CPPSUL, Bagé, RS, Brazil) selected a similar breed using, however, Nelore (Zebu) instead of Brahman cattle as the Bos indicus component. The selection program began in 1945 and the resultant herd, Brangus Ibagé, has a 5/8 Aberdeen Angus and 3/8 Nelore genetic composition (Chagas et al., 1972).

In this paper we studied the effect of crossbreeding and selection on the genetic diversity of this Brazilian hybrid herd, through the investigation of four microsatellites. Its relationship with other European breeds was also evaluated.

\section{MATERIAL AND METHODS}

Blood samples of 100 Brangus Ibagé animals ( 70 females and 30 males) were collected from the jugular vein using ACD as anticoagulant. DNA was extracted from total blood according to Plante et al. (1992). Four STRs were investigated: two CCA repeats, BMS3013 at chromosome 4 (Stone et al., 1996) and BMS3004 at chromosome 18 (Stone et al., 1996), and two CA arrays, HEL10 at chromosome 19 (Kaukinen and Varvio, 1993) and TGLA122 at chromosome 21 (Crawford et al., 1995). All microsatellites were PCR amplified as described by Stone $e t$ al. (1996). TGLA122 PCR amplification was, however, optimized using a touchdown method, as described by Crawford et al. (1995). PCR products were analyzed by vertical electrophoresis in $10 \%$ non-denaturing polyacrylamide gels following Lahiri et al. (1997). Hardy-Weinberg equilibrium was evaluated by exact tests (Louis and Dempster, 1987, or Gou and Thompson, 1992) using the GENEPOP computer program (Raymond and Rousset, 1995). Polymorphic information content (PIC) was estimated according to Botstein et al. (1980). Mean heterozygosity $(\mathrm{H})$ and Nei's measure of gene diversity $\left(\mathrm{H}_{\mathrm{T}}, \mathrm{H}_{\mathrm{S}}\right.$ and $\mathrm{G}_{\mathrm{ST}}$; $\left.\mathrm{Nei}, 1987\right)$ were used to quantify the degree of genetic variation within and

\footnotetext{
${ }^{1}$ Departamento de Genética, Universidade Federal do Rio Grande do Sul, Caixa Postal 15053, 91501-970 Porto Alegre, RS, Brasil. Send correspondence to T.A.W. Fax: +55-51-319-2011. E-mail: weimer@vortex.ufrgs.br

${ }^{2}$ Centro de Ciências Rurais, Universidade Federal de Santa Maria, 97105-900 Santa Maria, RS, Brasil.

${ }^{3}$ EMPRAPA/CPPSUL (Empresa Brasileira de Pesquisas Agropecuárias/Centro de Pesquisas de Pecuária dos Campos Sul Brasileiros, Laboratório de Reprodução Animal), Caixa Postal 242, 96400-970 Bagé, RS, Brasil.
} 
between populations. These computations were performed considering various levels of population subdivision, using DSW software (a modified version of the DISPAN computer package, T. Ota, Center of Human Genetics, Boston University). The $\mathrm{D}_{\mathrm{SW}}$ (stepwise-weighted genetic distance; Shriver et al., 1995) was obtained also using the DSW program. The neighbor-joining (NJ, Saitou and Nei, 1987) and UPGMA (Sneath and Sokal, 1973) trees based on this matrix distance were made with the same software.

\section{RESULTS AND DISCUSSION}

Allele frequencies estimated from genotypes for each locus (genotypic distributions available from the authors on request) are presented in Table I. Genotype distributions are in Hardy-Weinberg equilibrium in all systems. Low variability was found in BMS3013, with only two alleles, but BMS3004, HEL10, and TGLA122 presented high levels of diversity. The low variability observed in BM3013 is expected since trinucleotide repeats are in general less variable than dinucleotide repeats.

Although comparison of our frequency data on BMS3013, BMS3004 and HEL10 with that of other cattle populations was not possible, the alleles found herein had the same lengths as those described elsewhere (Bishop et al., 1994, Stone et al., 1996). Comparing TGLA122 with other taurine samples we found that TGLA122*155 and TGLA122*163 alleles are being described here for the first time. These genes are possibly characteristic of Zebu animals; however, no data could be found for Zebu cattle in the literature and only nine taurine samples have been so far investigated.

Genetic variability parameters are presented in Table II. Mean heterozygosity (54\%) showed high diversity levels in this cattle. Heterozygosity and PIC estimates are normally correlated and, as expected based on gene variability, TGLA122 showed the highest and BMS3013 the lowest values for both parameters.
The gene diversity analysis of the present population and other cattle samples was made using TGLA122 only since no data could be found for the other STRs investigated. As no data on Zebu cattle were found, only taurine animals were included in the analysis. Computations were based on eleven populations [Bison bison (Mommens et al., 1998); Red Angus, South Devon, Gelbvieb, Simental, Saler (Heyen et al., 1997); Holstein Friesian, Belgian Red Pied, Belgian Blue, East Flemish (Peelman et al., 1998) and Brangus Ibagé] and various levels of subdivision (Table III). Bison bison was included here and in the phylogenetic analyses as an outgroup. Total genetic variation $\left(\mathrm{H}_{\mathrm{T}}\right)$ ranged from 73 to $87 \%$, mostly due to intrapopulational $\left(\mathrm{H}_{\mathrm{S}}\right)$ diversity. Considering all populations, only $16 \%$ of their variability was due to interpopulational diversity $\left(\mathrm{G}_{\mathrm{ST}}{ }^{\prime}\right)$, a similar value to those observed for British cattle, the most differentiated animals. Between Brangus Ibagé and Red Angus only 7\% of the diversity was due to interpopulational variability. This high intrapopulational diversity observed in all subdivision levels is expected in comparisons involving racial groups from the same species.

The matrix of $D_{\text {sw }}$ genetic distance among the same populations analyzed for diversity is presented in Table IV. Although geographically distant populations, data comparisons showed a high degree of similarity, the distances varying from zero (Simental x Saler) to 2.1 (Gelbvieb x Bison). On the other hand, although a taurine-Zebu hybrid, Brangus Ibagé presented high similarity to the British Red Angus population $\left(\mathrm{D}_{\mathrm{sw}}=0.05\right)$.

The UPGMA and neighbor-joining phylogenetic trees based on $D_{\text {sw }}$ distances are presented in Figure 1. There are great similarities between both trees, the main difference being the position of Belgian cattle (BB, EF, HF, and BRP): this cluster observed using the UPGMA method does not appear in the neighbor-joining tree.

The relationship among the taurine animals merits special attention for three reasons:

Table I - Allele frequencies observed at the four loci investigated.

\begin{tabular}{|c|c|c|c|c|c|c|c|}
\hline \multicolumn{2}{|c|}{$\begin{array}{l}\text { BMS3013 } \\
(\mathrm{N}=100)\end{array}$} & \multicolumn{2}{|c|}{$\begin{array}{c}\text { BMS3004 } \\
(\mathrm{N}=99)\end{array}$} & \multicolumn{2}{|c|}{$\begin{array}{l}\text { HEL10 } \\
(\mathrm{N}=97)\end{array}$} & \multicolumn{2}{|c|}{$\begin{array}{c}\text { TGLA122 } \\
(\mathrm{N}=92)\end{array}$} \\
\hline Allele & Frequency & Allele & Frequency & Allele & Frequency & Allele & Frequency \\
\hline$* 103$ & 0.06 & $* 129$ & 0.73 & $* 98$ & 0.08 & $* 141$ & 0.10 \\
\hline \multirow[t]{10}{*}{ *112 } & 0.94 & $* 132$ & 0.24 & *104 & 0.36 & $* 143$ & 0.07 \\
\hline & & $* 138$ & 0.03 & $* 106$ & 0.09 & $* 145$ & 0.10 \\
\hline & & & & *108 & 0.23 & $* 147$ & 0.10 \\
\hline & & & & $* 110$ & 0.15 & $* 149$ & 0.08 \\
\hline & & & & $* 112$ & 0.06 & $* 151$ & 0.24 \\
\hline & & & & $* 114$ & 0.02 & $* 153$ & 0.10 \\
\hline & & & & & & $* 155$ & 0.07 \\
\hline & & & & & & $* 159$ & 0.03 \\
\hline & & & & & & $* 161$ & 0.08 \\
\hline & & & & & & $* 163$ & 0.03 \\
\hline
\end{tabular}

$\mathrm{N}=$ Number of samples investigated. 
First, the position of the South Devon sample, that clustered with the Bison bison (the outgroup) rather than with the other British breed (Red Angus). This grouping is probably due to the greater similarity observed in TGLA122 allele frequencies between these two breeds; however, the comparison involved only one locus and the results are therefore sensitive to sampling effects. All the other clusters satisfy expectations generated by the geographic origin of the various samples.

Second, the UPGMA algorithm presupposing constant evolutionary rates provides a more coherent clustering based on animal origin than neighbor-joining. However, according to Nei (1987), UPGMA, despite its simplicity, generally yields a quite reasonable tree at least when

Table II - Genetic variability parameters.

\begin{tabular}{|lcc|}
\hline Loci & $\begin{array}{c}\text { Average } \\
\text { heterozygosity }(\mathrm{H})\end{array}$ & $\begin{array}{c}\text { Polymorphic } \\
\text { information content }\end{array}$ \\
\hline BMS3013 & 0.113 & 0.106 \\
BMS3004 & 0.413 & 0.348 \\
HEL10 & 0.775 & 0.739 \\
TGLA122 & 0.881 & 0.865 \\
Mean heterozygosity & 0.545 & \\
\hline
\end{tabular}

Table III - Genetic diversity considering Brangus-Ibagé cattle and other taurine populations.

\begin{tabular}{|c|c|c|c|}
\hline Populations (N) & $\mathrm{H}_{\mathrm{T}}$ & $\mathrm{H}_{\mathrm{s}}$ & $\mathrm{G}_{\mathrm{ST}}{ }^{\prime}$ \\
\hline $\begin{array}{l}\text { Brangus Ibagé and } \\
\text { Red Angus (2) }\end{array}$ & 0.827 & 0.796 & 0.073 \\
\hline $\begin{array}{l}\text { Brangus Ibagé and } \\
\text { British Cattle (3) }\end{array}$ & 0.836 & 0.739 & 0.163 \\
\hline $\begin{array}{l}\text { Continental European } \\
\text { Cattle (3) }\end{array}$ & 0.726 & 0.707 & 0.037 \\
\hline Belgian Cattle (4) & 0.822 & 0.782 & 0.054 \\
\hline All populations (11) & 0.865 & 0.735 & 0.162 \\
\hline
\end{tabular}

$\mathrm{H}_{\mathrm{T}}=$ Total diversity; $\mathrm{H}_{\mathrm{S}}=$ variability within population; $\mathrm{G}_{\mathrm{ST}}{ }^{\prime}=$ gene differentiation coefficient. British Cattle: Red Angus and South Devon; Continental European Cattle: Gelbvieb, Saler and Simental; Belgian Cattle: Belgian Red Pied, Belgian Blue, Holstein Friesian and East Flemish. comparing organisms with similar physiology and generation time, such as races of the same species.

The third reason is the position of Brangus Ibagé clustering with Red Angus. Since Brangus Ibagé is a hybrid breed, the pattern expected was a cluster grouping all British cattle and then joining with Brangus Ibagé. However, these animals were selected based on morphological characteristics

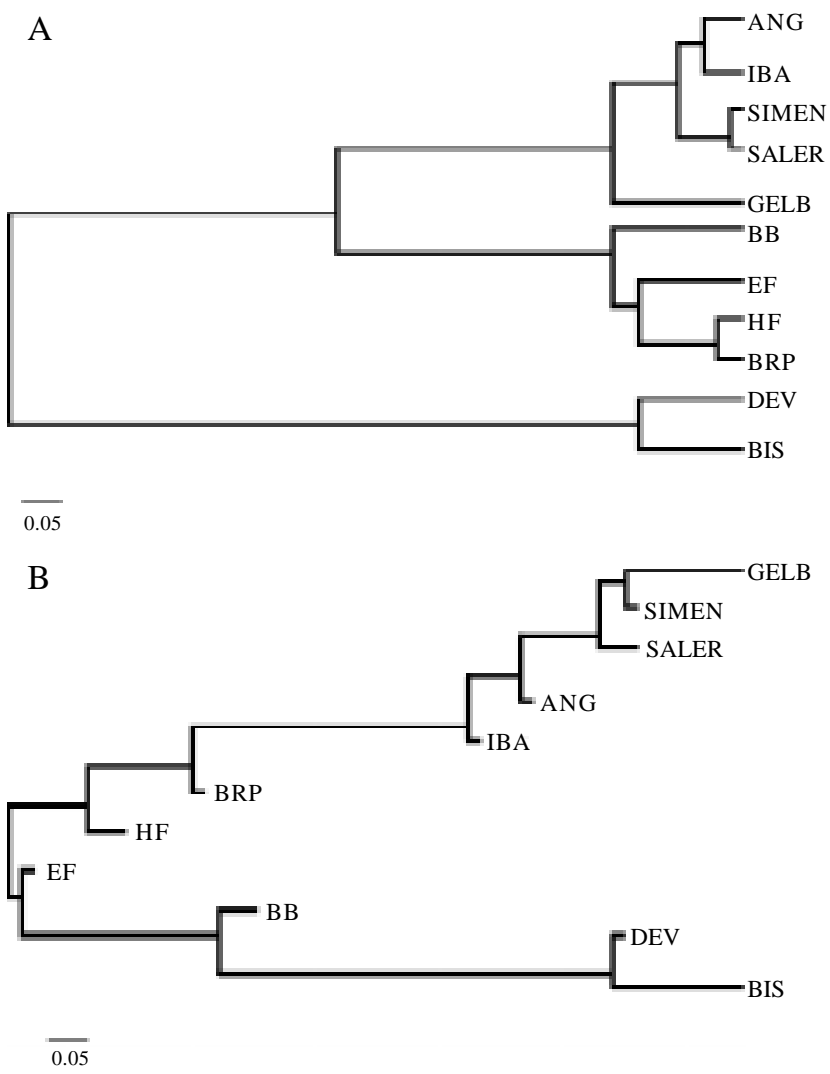

Figure 1 - UPGMA (A) and neighbor-joining (B) trees generated from $\mathrm{D}_{\mathrm{sw}}$ distance matrix. No bootstrap could be made since only TGLA122 was employed in the analysis. The trees were rooted using the midpoint method; $\mathrm{ANG}=$ Red Angus; IBA = Brangus Ibagé; SIMEN = Simental; SALER $=$ Saler $;$ GELB $=$ Gelbvieb $; \mathrm{BB}=$ Belgian Blue $; \mathrm{EF}=$ East Flemish; $\mathrm{HF}=$ Holstein Friesian; BRP = Belgian Red Pied; DEV = South Devon; BIS = Bison bison .

Table IV - Genetic distance matrix obtained with $\mathrm{D}_{\mathrm{sw}}$ distance based on TGLA122 locus in 11 bovine populations.

\begin{tabular}{|c|c|c|c|c|c|c|c|c|c|c|}
\hline Populations & $\begin{array}{c}\text { Red } \\
\text { Angus }\end{array}$ & $\begin{array}{l}\text { South } \\
\text { Devon }\end{array}$ & Gelbvieb & Simental & Saler & $\begin{array}{c}\text { Brangus } \\
\text { Ibagé }\end{array}$ & $\begin{array}{c}\text { Holstein } \\
\text { Friesian }\end{array}$ & $\begin{array}{l}\text { Belgian Red } \\
\text { Pied }\end{array}$ & $\begin{array}{c}\text { East } \\
\text { Flemish }\end{array}$ & $\begin{array}{c}\text { Belgian } \\
\text { Blue }\end{array}$ \\
\hline S. Devon & 1.12 & & & & & & & & & \\
\hline Gelbvieb & 0.15 & 1.88 & & & & & & & & \\
\hline Simental & 0.06 & 1.16 & 0.09 & & & & & & & \\
\hline Saler & 0.15 & 0.98 & 0.21 & 0.00 & & & & & & \\
\hline B. Ibagé & 0.05 & 1.01 & 0.19 & 0.05 & 0.08 & & & & & \\
\hline H. Friesian & 0.35 & 0.66 & 0.87 & 0.61 & 0.63 & 0.34 & & & & \\
\hline B. Red & 0.21 & 0.85 & 0.54 & 0.34 & 0.37 & 0.17 & 0.04 & & & \\
\hline E. Flemish & 0.41 & 0.45 & 0.82 & 0.40 & 0.31 & 0.27 & 0.18 & 0.09 & & \\
\hline B. Blue & 0.75 & 0.41 & 1.38 & 0.92 & 0.88 & 0.69 & 0.10 & 0.25 & 0.20 & \\
\hline Bison bison & 1.40 & 0.14 & 2.11 & 1.30 & 1.04 & 1.12 & 0.89 & 1.03 & 0.48 & 0.63 \\
\hline
\end{tabular}


with the aim to obtain a beef type animal that would retain the Nelore natural rusticity, with the excellent Angus meat quality. Therefore, besides the fact that Brangus Ibagé has a greater Angus genetic composition, the environment where these animals are reared or the genetic selection applied to them could be favoring Angus genotype.

We therefore conclude that: a) the genetic selection applied to the Brangus Ibagé cattle has not affected the high genetic variability expected for crossbreeds; b) although submitted to different genetic selective practices and living in diverse environments bovine herds presently maintain many interracial similarities; c) TGLA122, despite being highly polymorphic and presenting high levels of intrapopulational diversity, engenders consistent bovine phylogenies.

\section{ACKNOWLEDGMENTS}

This work was supported by Programa de Apoio a Núcleos de Excelência (PRONEX), Fundação de Amparo à Pesquisa do Estado do Rio Grande do Sul (FAPERGS), Financiadora de Estudos e Projetos (FINEP), Conselho Nacional de Desenvolvimento Científico e Tecnológico (CNPq), Coordenadoria de Estudos e Projetos (CAPES), and EMBRAPA/CPPSUL.

\section{RESUMO}

Microssatélites ou repetições curtas em tandem (STRs) são marcadores moleculares de relativa abundância no genoma e apresentam alto grau de polimorfismo, constituindo-se numa excelente ferramenta para a caracterização das populações. Este trabalho estimou a variabilidade genética de quatro microssatélites (BMS3013, BMS3004, HEL10 e TGLA122) em um rebanho híbrido de bovinos brasileiros (5/8 Aberdeen Angus x 3/8 Nelore), com os objetivos de verificar o efeito do cruzamento e das práticas seletivas na composição genética do rebanho e avaliar as relações genéticas destes animais com outras populações bovinas mundiais. Verificou-se uma baixa diversidade no BMS3013, mas alta variabilidade nos STRs BMS3004, HEL10 e TGLA122. No TGLA122 dois alelos novos estão sendo descritos pela primeira vez $(T G L A 122 * 155$ e TGLA122*163). É possível que esses genes sejam característicos de Zebu, uma vez que não ocorrem em outras raças taurinas investigadas até o momento. Uma baixa diversidade interpopulacional foi observada entre as populações taurinas, e os agrupamentos obtidos nas filogenias baseadas no TGLA122 foram coerentes com a origem geográfica dos rebanhos. Assim, apesar do TGLA122 ser altamente polimórfico e apresentar altos níveis de diversidade intrapopulacional, ele é um marcador muito eficiente para a construção de filogenias bovinas. Detectou-se uma grande similaridade entre Brangus Ibagé e Red Angus, apesar do Brangus Ibagé ser um rebanho híbrido com $3 / 8$ de genes Nelore. É possível que o ambiente onde esses animais vivem ou as práticas seletivas aplicadas ao rebanho estejam favorecendo o genótipo de Angus.

\section{REFERENCES}

Bishop, M.D., Kappes, S.M., Keele, J.W., Stone, R.T., Sunden, S.L.F., Hawkins, G.A., Toldo, S.S., Fries, R., Grosz, M.D., Yoo, J. and Beattie,
C.W. (1994). A genetic linkage map for cattle. Genetics 136: 619-639.

Botstein, D., White, R.L., Skolnick, M. and Davis, R.W. (1980). Construction of a genetic linkage map in man using restriction fragment length polymorphisms. Am. J. Hum. Genet. 32: 314-331.

Bradley, D.G., Loftus, R.T., Cunningham, P. and MacHugh, D.E. (1998). Genetics and domestic cattle origins. Evol. Anthropol. 6: 79-86.

Chagas, E.C., Caggiano, F.P. and Garcia, J.T.C. (1972). Formação do 5/8 Angus - 3/8 Zebu. Circular 57, Ministério da Agricultura, Departamento Nacional de Pesquisa Agropecuária, Pelotas, RS, pp. 8.

Crawford, A.M., Dodds, K.G., Ede, A.J., Pierson, C.A., Montgomery, G.W., Garmonsway, H.G., Beattie, A.E., Davies, K., Kappes, R.T., Stone, R.T., Nguyen, T.C., Penty, J.M., Lord, E.A., Broom, J.E., Buitkamp, J., Schwaiger, W., Epplen, J.T., Matthew, P., Mattheus, M.E., Hulme, D.J., Beh, K.J., McGraw, R.A. and Beattie, C.W. (1995). An autosomal genetic linkage map of the sheep genome. Genetics 140: 703-724.

Gou, S.W. and Thompson, E.A. (1992). Performing the exact test of HardyWeinberg proportions for multiple alleles. Biometrics 48: 361-372.

Heyen, D.W., Beever, J.E., Da, Y., Evert, R.E., Green, C., Bates, S.R., Ziegle, J.S. and Lewin, H.A. (1997). Exclusion probabilities of 22 bovine microsatellite markers in fluorescent multiplexes for semiautomated parentage testing. Anim. Genet. 28: 21-27.

Kaukinen, J. and Varvio, S.L. (1993). Eight polymorphic bovine microsatellites. Anim. Genet. 24: 148.

Keeling, P. (1997). What is Brangus world? http://www.brangusworld.com

Lahiri, D.K., Zhang, A. and Nurnberger, J.I. (1997). High resolution detection of PCR products from microsatellites marker using a nonradioisotopic technique. Bioch. Mol. Med. 60: 70-75.

Louis, E.J. and Dempster, E.R. (1987). An exact test for Hardy-Weinberg and multiple alleles. Biometrics 43: 805-811.

MacHugh, D.E., Shriver, M.D., Loftus, R.T., Cunningham, P. and Bradley, D.G. (1997). Microsatellite DNA variation and the evolution, domestication and phylogeography of Taurine and Zebu cattle (Bos taurus and Bos indicus). Genetics 146: 1071-1086.

Mommens, G., Van Zeveren, A. and Peelman, L.J. (1998). Effectiveness of bovine microsatellites in resolving paternity cases in American bison, Bison bison L. Anim. Genet. 29: 12-18.

Nei, M. (1987). Molecular Evolutionary Genetics. Columbia University Press, New York, pp. 512.

Peelman, L.J., Mortiaux, F., Van Zeveren, A., Dansercoer, A., Mommens, G., Coopman, F., Bouquet, Y., Burny, A., Renaville, R. and Portetelle, D. (1998). Evaluation of the genetic variability of 23 bovine microsatellite markers in four Belgian cattle breeds. Anim. Genet. 29: 161-167.

Plante, Y., Schmutz, S.M. and Lang, K.D.M. (1992). Restriction fragment length polymorphism in the mitochondrial DNA of cloned cattle. Theriogenology 38: 897-904.

Raymond, M. and Rousset, F. (1995). GENEPOP (version 1.2). Population genetics software for exact tests and ecumenicism. J. Hered. 86: 248249.

Ron, M., Blanc, Y., Band, M., Ezra, E. and Weller, J.I. (1996). Misidentification rate in Israeli dairy cattle population and its implications for genetic improvement. J. Dairy Sci. 79: 676-681.

Saitou, N. and Nei, M. (1987). The neighbor-joining method: a new method for reconstructing phylogenetic trees. Mol. Biol. Evol. 4: 406-425.

Shriver, M.D., Jin, L., Boerwinkle, E., Deka, R., Ferrell, R.E. and Chakraborty, R. (1995). A novel measure of genetic distance for highly polymorphic tandem repeat loci. Mol. Biol. Evol. 12: 914-920.

Simonsen, T.B., Siegismund, H.R. and Arctander, P. (1998). Population structure of African buffalo inferred from mtDNA sequences and microsatellite loci: high variation but low differentiation. Mol. Ecol. 7: 225-237.

Sneath, P.H.A. and Sokal, R.R. (1973). Numeral Taxonomy. Freeman and Company, San Francisco, pp. 573.

Stone, R.S., Kappes, S.M. and Beattie, C.W. (1996). Five polymorphic trinucleotide (CCA) bovine microsatellites. Anim. Genet. 27: 216.

Tautz, D. (1993). Notes on the definition and nomenclature of tandemly repetitive DNA sequences. In: DNA Fingerprint: State of the Science. (Pena, S.D.J., Chakraborty, R., Epplen, J.T. and Jeffreys, A.J., eds.). Birkäuser Verlag, Basel, pp. 21-28.

(Received June 23, 1999) 